\title{
Improvement of friable callus production of Boerhaavia paniculata Rich and the investigation of its lipid profile by GC/MS
}

\author{
JOANNE M.M. SOUZA ${ }^{1}$, STRAHILL BERKOV ${ }^{2}$ and ALBERDAN S. SANTOS ${ }^{1}$ \\ ${ }^{1}$ Universidade Federal do Pará, Instituto de Ciências Exatas e Naturais, Laboratório de Investigação Sistemática em \\ Biotecnologia e Biodiversidade Molecular/LabISisBio, Rua Augusto Correa, 01, Guamá, 66075-110 Belém, PA, Brasil \\ ${ }^{2}$ AgroBioInstitute, 8, Dragan Tzankov Blvd., 1164, Sofia, Bulgaria
}

Manuscript received on March 11, 2013; accepted for publication on September 9, 2013

\begin{abstract}
In this study, a protocol to induce high amount of friable callus of Boerhaavia paniculata RICH and a lipidomics technique were applied to investigate the profile of lipids to relate to those present in the roots of this plant that presented anti-inflammatory activity in the crude hexane extract. The callus culture was induced from seeds in solidified Murashige and Skoog medium containing different amounts of glucose and different concentrations of 2,4-Dichlorophenoxyacetic acid. The explants were kept in a germination chamber at $30 \pm 2^{\circ} \mathrm{C}$ with a photoperiod of $16 \mathrm{~h}$ under light intensity of $27 \mu \mathrm{mol} \mathrm{m}^{-2} \mathrm{~s}^{-1}$ for 4 weeks. The best results for friable callus formation and development of the biomass were obtained in the treatment containing $2.26 \mu \mathrm{M}$ 2.4-D and glucose (1.5\%; w/v). Lipidomics techniques were applied in hexane fraction showing higher concentrations of the steroids $\beta$-sitosterol $(3.53 \mathrm{mg} / 100$ $\mathrm{g}$ dc-dry cells), and fatty acids, especially 2-hydroxy-tetracosanoic acid $(0.34 \mathrm{mg} / 100 \mathrm{~g} \mathrm{dc})$, eicosanoic acid ( 86.25 $\mathrm{mg} / 100 \mathrm{~g} \mathrm{dc})$, stearic acid $(420.83 \mathrm{mg} / 100 \mathrm{~g} \mathrm{dc})$, tetradecanoic acid $(10.74 \mathrm{mg} / 100 \mathrm{~g} \mathrm{dc})$ and linoleic acid (100.61 $\mathrm{mg} / 100 \mathrm{~g} \mathrm{dc}$ ). The lipid profile of callus versus that found in the roots of wild plant is described in this work.
\end{abstract}

Key words: anti-inflammatory lipids, Boerhaavia paniculata, callus culture, lipid profile, medicinal plant.

$\begin{array}{ll}\text { Abreviations } \\ \text { FW } & \text { Fresh Weight } \\ \text { DW } & \text { Dry Weight } \\ \text { DC } & \text { Dry callus } \\ \text { MS } & \text { Murashige and Skoog medium } \\ \text { 2,4-D } & \text { 2,4-Dichlorophenoxyacetic acid }\end{array}$

\section{INTRODUCTION}

The culture of plant cells has emerged as a promising alternative for the production of plant metabolites in vitro, and this is because plant cells

Correspondence to: Alberdan Silva Santos

E-mail: alberdan@ufpa.br in the culture media present a large variety of growth characteristics for secondary metabolites production. In this sense, the relation of cell proliferation and product formation is the focus for the production of bioactive compounds in vitro. In general, the cells proliferation and compounds biosynthesis are separated phenomena, following each one its own favorable conditions.

Plant tissue culture represents a continuous effort to produce secondary metabolites under controlled conditions, favoring the attainment of higher amounts of active compounds, inducing and accumulating the metabolites of interest in 
a short period of time without interference of the environment (climate, soil, infestations and seasonality), without damaging the mother plant, and allowing the selection of cultivars with high production of metabolites of interest (Dicosmo and Misawa 1995, Ramachandran Rao and Ravishankar 2002, Mulabagal and Tsay 2004), although bioactive compounds production can be responses to the external stimuli on the cells.

Since the beginning of the human history, plants have been the main sources of medicine and nowadays are widely used for more than $80 \%$ of the world population (Mhaskar et al. 2010). This is because many plants produce metabolites with biological activities of great interest, and frequently, only the major metabolites produced by the organism that are more easily isolated because they have technical feasibility of being exploited and marketed as drugs, chemicals, fragrances, food additives and pesticides (Balandrin and Klocke 1988). Moreover, the metabolites presented in small concentrations suggest potential activities higher than those with higher concentrations; however, few studies have been addressed to this aspect of the biological and chemical plant metabolites. In recent years, traditional medicine has become a matter of global importance in terms of natural resources being exploited widely and many species of medicinal plants have been scientifically evaluated because of their potential medical applications, but the natural habitats of medicinal plants are rapidly disappearing. In the same way, the ethnopharmacological information is disappearing too, and this is more pronounced in industrialized countries (Weldegerima 2009). Also, most of the active compounds in these species are usually found in low concentrations (Mulabagal and Tsay 2004), and to solve this problem several techniques have been developed (Jiao et al. 2002, Van Ruth et al. 2003), being the production of these metabolites in vitro one of the interesting alternative.
The species Boerhaavia paniculata Rich belongs to the Nyctaginaceae family and has several botanical synonyms as Boerhaavia coccinea and Boerhaavia diffusa (Sá 2011, Tropicos 2011), and has been popularly used in the treatment of kidney and bladder ills, biliary fever, malaria, jaundice, congestion of the liver and spleen, dropsy, as anti-hemorrhagic and especially on urinary and uterine system inflammations (Iqbal et al. 2011). Thus, several studies have been performed on plants of the genus Boerhaavia which were found to present pharmacological properties such as antimicrobial activity, anti-inflammatory, anti-fibrinolytic and anti-convulsive actions (Méndez et al. 2001). Despite the reported studies, the chemistry of bioactive compounds and its pharmacological properties is still poorly understood. Recent studies in our laboratories indicated that a fraction from hexane extract of B. paniculata presented high biological activity acting as anti-inflammatory, being responsible for the pharmacological effects found in this plant, even though, nothing has been written about the lipid profile of this species. Few studies with species of Nyctaginaceae applying biotechnology techniques are found in the literature, being few related with the in vitro production of metabolites and biomass development behavior, mainly of the genus Boerhaavia (Gupta et al. 2004, Rownaq and Hossain 2010, Roy 2008, Santos et al. 2007, Sudarshana et al. 2008, Zaccai et al. 2007).

The development of an efficient protocol for induction of friable calli involved the suitability of many factors such as adjustment of culture medium, type of explant and conditions of maintenance of the in vitro culture. However to study the in vitro production of metabolites besides the development of an efficient protocol for callus induction, it was firstly necessary to obtain large amounts of calli biomass. For this reason, the present study was developed to establish an efficient protocol for callus induction, friable biomass production and studying the in vitro production of 
metabolites to investigate the lipid profile and its similarity with the anti-inflammatory activity of the lipids fraction from the wild roots of $B$. paniculata.

\section{MATERIALS AND METHODS}

PLANT SOURCE

Seeds of B. paniculata Rich. were collected in the Garden of medicinal plants at EMBRAPA Amazônia Oriental. The plants were identified and voucher number of the specimen was registered (code IAN No. 184191), in the IAN Herbarium of EMBRAPA Amazônia Oriental, Belém-Pará, Brazil.

\section{PREPARATION OF EXPLANTS FOR THE INOCULUM}

Seeds of B. paniculata were rinsed with two drops of Tween $80^{\circledR}$ and washed thoroughly under running tap water, then immersed in sodium dodecyl sulfate $(5 \%$; $/ v)$ for 2 min under agitation, and washed with sterile distilled water. The seeds were immersed in $75 \%$ ethanol for 1 minute, then in a solution of sodium hypochlorite $(5 \%$; $/ \mathrm{v})$ containing two drops of Tween $80^{\circledR}$ for 20 min under stirring, and washed three times in sterile distilled water under aseptic conditions. The seeds were left in a solution containing $50 \mathrm{mgL}^{-1}$ of tetracycline under stirring (50-100 rpm) for $4 \mathrm{~h}$. After this, the seed coats were removed, and were immersed in $0.5 \%$ sodium hypochlorite, and solution of tetracycline $50 \mathrm{mg} \mathrm{L}^{-1}$, dried on sterile filter paper (adapted from Brasileiro and Lacorte 1998, Sambrook et al 1989), (Seed Aseptic Procedure: SA-Procedure), and inoculated into bottles containing the culture medium for callus induction.

\section{INOCULUMS AND FRIABLE CALLUS INDUCTION FROM}

SEEDS OF B. paniculata

After the sterilization procedures as described above, explants were inoculated into cylindrical flasks (10x5 cm) containing $30 \mathrm{ml}$ of culture medium for callus induction.

In preliminary experiments developed in our laboratories, the culture medium $1 / 2 \mathrm{MS}$ and MS (Murashige ans Skoog 1962), with different concentrations and combinations of the growth regulators BAP (Benzylaminopurine) and 2,4-D, the influence of the sources carbon concentrations (glucose and sucrose), culture medium with and without coconut water $(10 \% ; \mathrm{v} / \mathrm{v})$, and different types of explants (seeds without tegument, hypocotyl and leaf segments from seedlings germinated in vitro) were investigated. The results showed that $1 / 2$ MS medium, seeds without tegument, glucose as carbon source and coconut water were the most suitable for further experiments to obtain callus induction. Based on this preliminary investigation, seeds without tegument were inoculated in half strength MS basal medium ( $1 / 2$ MS) supplemented with different concentrations of 2,4-D (0.0, 2.26 $\mu \mathrm{M}$ and $4.53 \mu \mathrm{M})$, different glucose concentrations $(0.0 ; 1.5 \%$ and $3 \% ; \mathrm{w} / \mathrm{v})$ supplemented with coconut water $(10 \% \mathrm{v} / \mathrm{v})$ and solidified with agar $(0.8 \% \mathrm{w} / \mathrm{v})$ (Himedia Co., Mumbai, India). The $\mathrm{pH}$ was adjusted to 5.8 before autoclaving at $121^{\circ} \mathrm{C}$ for $15 \mathrm{~min}$. The explants were kept in a germination chamber at $30 \pm 2^{\circ} \mathrm{C}$ with a photoperiod of $16 \mathrm{~h}$ under light intensity of $27 \mu \mathrm{mol} \mathrm{m} \mathrm{m}^{-2} \mathrm{~s}^{-1}$ for 4 weeks. Callus induction was investigated for 30 days.

\section{Callus Production and Accumulation of}

\section{METABOLITES IN VITRO}

To produce friable calli and increase the biomass, calli formed from seeds were sub-cultured every month in $1 / 2$ MS medium with $1.5 \%(\mathrm{w} / \mathrm{v})$ glucose, $10 \%(\mathrm{v} / \mathrm{v})$ coconut water, $2.26 \mu \mathrm{M}$ of 2,4-D and solidified with agar $0.8 \%(\mathrm{w} / \mathrm{v})$. The calli were sub-cultured in a germination chamber in the same way as described above. The calluses were observed for 30 days, with removal of three cylindrical flasks every 5 days (sacrifice sampling). During this period, measurements of FW (fresh weight) and DW (dry weight) were taken.

\section{EVALUATION OF CALLi BIOMASS GROWTH}

The growth of friable calli was determined by sampling sacrifice. Initially, the mass of calluses were measured and inoculated into cylindrical flasks 
containing $1 / 2$ MS to increase the biomass, added glucose $(1.5 \% ; \mathrm{w} / \mathrm{v})$, coconut water $(10 \% ; \mathrm{v} / \mathrm{v}), 2.26$ $\mu \mathrm{M}$ of $2,4-\mathrm{D}$ and solidified with agar $(0.8 \% ; \mathrm{w} / \mathrm{v})$. The calli were observed for 30 days, with removal of three cylindrical flasks every five days (sacrifice sampling). During this period, measurements of FW (fresh weight) and DW (dry weight) were taken. Every five days, cylindrical flasks containing the callus were removed from the culture and the FW was measured. Later, calli collected were dried in an oven at $60^{\circ} \mathrm{C}$ for $48 \mathrm{~h}$ and the DW was determined. It was also determined the growth rate (GR) as the factor that describes how many times the biomass grew compared to the initial inoculum. The calli were stored at $-4^{\circ} \mathrm{C}$ for further analysis.

Procedure to Obtain the ORganic Fractions From CALli

The study of metabolites induction was evaluated in the biomass callus by sacrifice sampling during exhaustion of the carbon source. The calli were collected and dried in an oven at $60^{\circ} \mathrm{C}$ for $48 \mathrm{~h}$. After, they were crushed to a powder, $100 \mathrm{mg}$ was transferred to a glass column $(1 \mathrm{~cm} \times 30$ $\mathrm{cm})$, previously packed with Silica 60 mesh $(2 \mathrm{~g})$ used as stationary phase. The elution was done using organic solvents in increasing order of polarity: hexane (100\%), ethyl acetate $(100 \%)$ and hydroethanol solution at $80 \%(\mathrm{v} / \mathrm{v})$. Each fraction was performed with two replicates each $24 \mathrm{~h}$, and fractions of the same solvent were pooled. The extracts were collected in vials and the solvent was evaporated. The dried extracts were stored at $-4^{\circ} \mathrm{C}$ for further analysis.

\section{EVAluATION OF THE LIPID PROFILE FROM CALLUSES}

The analyses of the chemical profile of the hexane fraction from calli of B. paniculata were performed by GC/MS. The data were obtained on Agilent 5975C GC/MS system. The fraction was analyzed after derivatization as described here: an aliquot of $10 \mathrm{mg}$ of extract was dissolved in $500 \mu \mathrm{l}$ of methanol acidified with $2 \%$ sulfuric acid $\left(\mathrm{H}_{2} \mathrm{SO}_{4}\right)$ in microtube and heated at $90^{\circ} \mathrm{C}$ for $2 \mathrm{~h}$. After cooling, the solution was extracted with $500 \mu \mathrm{l}$ of n-hexane three times. The combined fractions were washed with sodium bicarbonate $\left(\mathrm{NaHCO}_{3}\right) 4 \%$ in water. The mixture was passed through a Pasteur pipette containing 100 $\mathrm{mg}$ of anhydrous sodium sulfate $\left(\mathrm{Na}_{2} \mathrm{SO}_{4}\right)$. After evaporating the solvent with Speed-vac, the mixture was silylated in $50 \mu \mathrm{l}$ of pyridine and $50 \mu \mathrm{l}$ of $\mathrm{N}, \mathrm{O}$-bis (trimethylsilyl) trifluoroacetamide (BSTFA). After this procedure, it was added $300 \mu$ of chloroform, and $1 \mu \mathrm{l}$ of the mixture was analyzed by GC/MS. The system was operated under the following conditions: Oven was maintained at a temperature program which started with $100^{\circ} \mathrm{C}$ for $2 \mathrm{~min}$, with ramp $15^{\circ} \mathrm{C}$ for $1 \mathrm{~min}$, rising to $180^{\circ} \mathrm{C}$ for $1 \mathrm{~min}$ and remained with the second ramp $5^{\circ} \mathrm{C}$ for $1 \mathrm{~min}$, raising up to $300^{\circ} \mathrm{C}$ and kept at this temperature for $10 \mathrm{~min}$. The injection mode was $1 \mu \mathrm{l}$ of split (1:5). The linear velocity carrier gas was $1.2 \mathrm{ml} \mathrm{min}{ }^{-1}$, using helium as carrier gas. The column used was HP 5MS (5\% Phenyl Methyl Silox - $30 \mathrm{~m}$ x $0.25 \mathrm{~mm}$ id x $0.25 \mu \mathrm{m}$ film thickness). The heater and the transfer line was kept at $250^{\circ} \mathrm{C}$. The compounds were identified by comparison of their mass spectra with those of the lipid library, NIST 05 database, and online available plantspecific database (The Golm Metabolome Database; http://csbdb.mpimp-golm.mpg.de/csbdb/gmd/home/ gmd_sm.html). The measured mass spectra were deconvoluted by the Automated Mass Spectral Deconvolution and Identification System (AMDIS) before comparison with the databases. The spectra of individual components were transferred to the NIST Mass Spectral Search Program MS Search 2.0 where they were matched against reference compounds.

\section{EXPERIMENTAL DESIGN AND DATA ANALYSIS}

The experiment of callus induction was performed with a completely randomized design with $3 \times 3$ factorial designs, resulting in nine treatments with a minimum of 10 replicates and all experiments were repeated three times. Statistical analysis was done with the MINITAB 14 software. The Tukey test 
was used to compare the means with significance level of $P \leq 0.05$. The treatments were analyzed by the percentage of callus induction $(\mathrm{CI})$, percentage of friable callus induction (FC) and the average fresh weight $(\mathrm{FW})$ of sacrifice sample. Data were expressed as mean \pm standard error. For all analyses, the student's $t$ - test was used in a multi comparison between control and samples.

\section{RESULTS AND DISCUSSION}

INDUCTION OF FRIABLE CALLUS FROM SEEDS OF B. paniculata

The seeds of B. paniculata treated as SA-Procedure were not contaminated in vitro. Contrariwise, in a preliminary aseptic procedure using only ethanol and sodium hypochlorite with different concentrations and time of exposure, had presented high levels of bacterial and fungal contamination (80\%), and the ones not contaminated had low formation of callus, mostly hard and nodular callus, with high rate of oxidation and low friability. The best results were obtained with seed aseptically prepared and without tegument as explant, $1 / 2 \mathrm{MS}$ in the culture medium, glucose as carbon source and coconut water as source of vitamins, amino acids and phitohormones. The wide application of coconut water in plant tissue culture is justified by its unique chemical composition, it has been widely used as a growth supplement of calli in the culture medium stimulating rapid amount of biomass and friability (Souza 2012). Further, coconut water promotes improved growth of calli and friability. Apart from coconut water has a complex variable chemical composition, it has been widely used in the plant tissue culture industry as a growth-promoting component in the formulation of tissue culture media (Yong et al. 2009). From a scientific point of view, the use of coconut water is not reproducible in concentration of its chemical components as it precludes the possibility for investigation the effects of individual components of the medium with any degree of accuracy, but independently of its complexity, its use presents good effect on the friability of calli due to presenting growth regulatory properties, and the most significant chemical group is the phytohormone, being kinetin $\mathrm{N}$-furfuruladenine, a cytokinin, the main constituent. The procedure described here is relatively simple and consistent with the development of calli biomass and friability.

Using these results we performed an assay to obtain a culture medium for callus induction, the most suitable in Boerhaavia. Table I presents treatments with different concentrations of glucose and 2,4-D in $1 / 2$ MS medium supplemented with $10 \%(\mathrm{v} / \mathrm{v})$ of coconut water for adjustment of the culture medium for callus induction.

With these results it can be seen that the seeds, without the coats, used as explants, favored the induction and production of calli. This phenomenon occurred after one week of cultivation and all treatments induced callus with color ranging from beige to light brown, indicating that the explants, medium and culture conditions were suitable to induce friable callus. The cells biomass grew vigorously in the treatment $5[1 / 2 \mathrm{MS}, 10 \%(\mathrm{v} / \mathrm{v})$ coconut water $+1.5 \%(\mathrm{w} / \mathrm{v})$ glucose and $2.26 \mu \mathrm{M}$ of 2,4-D], which showed $100 \%$ of friability rate and high growth amount of calli represented by fresh weight of $545 \mathrm{mg}$ per sample (presented in a cylindrical flask). As a comparison, Gupta et al. (2004) obtained calli from stem, leaf and root segments of $B$. diffusa plantlets produced in vitro on modified MS medium (MS1) supplemented with $0.5 \mathrm{mgl}^{-1} \mathrm{BA}, 1.0 \mathrm{mgl}^{-1}$ NAA and $2.0 \mathrm{mgl}^{-1}$ 2,4-D. However, the best results were obtained in stem explants subcultured on the same medium but supplemented with decreased concentration of 2,4-D $\left(1.0 \mathrm{mgl}^{-1}\right)$.

Any plant tissue can be used as explants in vitro due to the totipotency of cells. In general, hypocotyls, endosperm of seeds, young leaves, immature embryos or inflorescences that have a higher proportion of meristematic tissue and greater ability to express totipotency are preferred (Grattapaglia and Machado 1998, Lindsey and Jones 1992), and that 
TABLE I

Callus induction of Boerhaavia paniculata Rich in $1 / 2$ MS medium supplemented with $10 \%(v / v)$ coconut water and different concentrations of glucose and 2,4-D.

\begin{tabular}{|c|c|c|c|c|}
\hline & TREATMENTS & $\begin{array}{l}\text { CALLI INDUCTION (\%) } \\
\text { (Avarage + S.E.) }\end{array}$ & $\begin{array}{l}\text { FRIABLE CALLI (\%) } \\
\text { (Avarage+ S.E.) }\end{array}$ & $\begin{array}{l}\text { FRESH WEIGHT (mg) } \\
\text { (Avarage+ S.E.) }\end{array}$ \\
\hline 1 & $1 / 2 \mathrm{MS}$ & $95,0 \pm 15,8 \mathrm{a}$ & $100,0 \pm 0,0 \mathrm{a}$ & $150,7 \pm 97,2 b c$ \\
\hline 2 & $1 / 2 \mathrm{MS}+2,265 \mu \mathrm{M} 2,4-\mathrm{D}$ & $65,0 \pm 41,2 \mathrm{ab}$ & $80,0 \pm 42,2 \mathrm{a}$ & $309,7 \pm 69,2 b$ \\
\hline 3 & $1 / 2 \mathrm{MS}+4,53 \mu \mathrm{M} 2,4-\mathrm{D}$ & $89,0 \pm 16,5 \mathrm{ab}$ & $88,9 \pm 33,3$ a & $161,8 \pm 82,5 \mathrm{bc}$ \\
\hline 4 & $1 / 2 \mathrm{MS}+1,5 \%$ glucose & $55,0 \pm 36,9 b$ & $80,0 \pm 42,2 \mathrm{a}$ & $198,7 \pm 66,6 \mathrm{bc}$ \\
\hline 5 & $1 / 2 \mathrm{MS}+1,5 \%$ glucose $+2,265 \mu \mathrm{M} 2,4-\mathrm{D}$ & $63,0 \pm 28,6 \mathrm{ab}$ & $100,0 \pm 0,0 \mathrm{a}$ & $545,0 \pm 13,7 \mathrm{a}$ \\
\hline 6 & $1 / 2 \mathrm{MS}+1,5 \%$ glucose $+4,53 \mu \mathrm{M} 2,4-\mathrm{D}$ & $80,8 \pm 35,0 \mathrm{ab}$ & $87,5 \pm 35,4 \mathrm{a}$ & $290,7 \pm 155,8 b$ \\
\hline 7 & $1 / 2 \mathrm{MS}+3,0 \%$ glucose & $63,0 \pm 41,5 \mathrm{ab}$ & $33,3 \pm 50,0 \mathrm{~b}$ & $79,6 \pm 4,3 \mathrm{c}$ \\
\hline 8 & $1 / 2 \mathrm{MS}+3,0 \%$ glucose $+2,265 \mu \mathrm{M} 2,4-\mathrm{D}$ & $95,0 \pm 15,8 \mathrm{a}$ & $54,5 \pm 47,8 \mathrm{ab}$ & $132,4 \pm 53,8 \mathrm{c}$ \\
\hline \multirow[t]{2}{*}{9} & $1 / 2 \mathrm{MS}+3,0 \%$ glucose $+4,53 \mu \mathrm{M} 2,4-\mathrm{D}$ & $84,1 \pm 28,0 \mathrm{ab}$ & $63,6 \pm 45,2 \mathrm{ab}$ & $115,6 \pm 53,9 \mathrm{c}$ \\
\hline & $p$-value & $0,019 *$ & $0,003 * *$ & $0,00 * *$ \\
\hline
\end{tabular}

Means followed by the same lower case letters do not differ in Tukey test;

Callus induction rate and percentage of friable callus are given in percentage; fresh calli weight is given in milligram;

$\mathrm{SE}=$ Standard Deviation. $* 0.01<p<0.05$ differences are significant at $5 \%$; $* * p<0.01$ significant differences at $1 \%$ and $5 \%$.

is why seed may be good source of explants. Wang and Ha (2007) reported that seeds and seedlings had higher rate of callus induction when compared with young leaves or stems. Callus formation from explants is accompanied by a number of structural changes, and in cell metabolism which results in dedifferentiation of tissue. The morphology of the callus may be described as friable (loosely aggregated cells, with lower density) or compact (aggregated cells are thicker, with higher density) (Lindsey and Jones 1992). The friable calluses have different cell types with different structural and histochemical characteristics, mainly characterized by the presence of cells in rapidly small growing, isodiametric, with high frequency of cell divisions (Souza et al. 2011). These results are observed when callus formation showed a high degree of dedifferentiation and friability, which showed that the source of explants presented high meristematic system. The modified MS medium showed good results for several species, also $B$. paniculata presented excellent friability and biomass growth in this medium. The growth conditions, related to light and temperature are variable that depend on plant species, and the in vitro cultivation of $B$. paniculata was more effective at high temperatures and photoperiods of $16 \mathrm{~h}$ of light. The results for the rate of induction showed significant differences in the level of $5 \%$ in the Tukey test, and the rate of mass of friable calluses showed significant difference at $1 \%$ and $5 \%$ levels.

In the treatment $1(1 / 2 \mathrm{MS}$; coconut water $10 \%$ $\mathrm{v} / \mathrm{v})$ were observed high rate of callus induction $(95 \%)$ and friability (100\%), without the presence of growth regulator and glucose; even though with low average mass of callus (150 mg). These results differ from our preliminary experiments with seed without tegument in the same medium without addition of coconut water that did not show any callus induction, indicating that the presence 
of coconut water in the culture medium improved the induction and especially the growth of callus in vitro. Coconut water presents a complex mixture of minerals and organic compounds, as glucose, fructose, amino acids, kinetin, kinetin derivatives and other compounds that may act individually or synergistically (Ge et al. 2004, 2005, CampbellFalck et al. 2000). However, coconut water is a complex mixture that remains widely used as additive in plant tissue culture with excellent results demonstrated in recent studies (Abraham et al. 2012, Ge et al. 2005, Kanwar et al. 2010, Karthikeyan et al. 2012). Here are two examples of applications: Peixe et al. (2007) have achieved success in the micropropagation of olives using coconut water and BAP in the culture; Roy (2008) also reported that the addition of coconut water in the medium increased both the number of buds and segments explants from nodal meristems of B. diffusa. As observed, the presence of kinetin and other cytokinins in coconut water as major phytohormones suggests its effectiveness as a supplement for culture growth and development of plant cells and tissues.

Analyzing the isolated effect of glucose in the treatment, without the presence of 2,4-D (treatments 4 and 7) showed that the percentage of callus induction was lesser than the medium without glucose, and this percentage was decreased with the increasing of glucose concentration. The same occurred with the friability of the callus and biomass development. In treatment $4(1 / 2 \mathrm{MS}$ with $10 \%$ coconut water and $1.5 \%$ glucose) can be observed the lowest rate of induction of all treatments, except for the induced callus that had a high friability and growth. Treatment 7 ( $1 / 2 \mathrm{MS}$ with $10 \%$ coconut water and $3 \%$ glucose) had a lowest rate friability (33\%) and less growth of the callus (79.6 mg) compared to all treatments. Probably, the absence of growth regulators and higher glucose concentration influenced these results, which suggest that the presence of carbohydrates had no positive effect in the medium associated with coconut water, and that the medium without carbohydrate, and only coconut water added was more efficient for induction callus formation. Sucrose is the most widely carbohydrate used in the nutritive media, supplying high growth rates in most species, however, addition of carbohydrate higher than $25 \mathrm{~g} / \mathrm{L}$ influences the osmotic potential of the culture medium which also has a strong influence on the morphogenesis of cells cultivated in vitro (Fuentes et al. 2000, Petersen et al. 1999).

According to Paiva Neto and Otoni (2003) the glucose concentration at $1.5 \%(\mathrm{w} / \mathrm{v})$ has lower osmotic potential $-0.205 \mathrm{MPa}$ than glucose and sucrose at a concentration of $3 \%(\mathrm{w} / \mathrm{v})$, which have osmotic potential of $-0.410 \mathrm{MPa}$ and $-0.237 \mathrm{MPa}$, respectively. The increase of the osmotic potential (concentration of solute) in the cells induces a reducing potential of water in the cells, promoting toxic effect. These differences in the osmotic potential can explain the best induction of calli of B. paniculata in the culture medium containing $1.5 \%$ glucose (lower osmotic potential).

Regarding the isolated effect of the growth regulator 2,4-D in the culture medium without carbohydrate (treatments 2 and 3), the calli exhibited a reduction in the percentage of induction and growth, but remained highly friable. Treatment 6 , with an intermediate concentration of glucose $(1.5 \% \mathrm{w} / \mathrm{v})$, presented high friability $(87.5 \%)$ and good growth of callus that was represented by the fresh weight $(290.7 \mathrm{mg})$. In high concentrations of glucose (treatments 8 and 9), was observed a slight increase in the rate of callus induction in relation to the intermediate doses $(1.5 \% \mathrm{w} / \mathrm{v})$, however, the rates of friability and biomass were lower than the other treatments with concentrations of $1.5 \%(\mathrm{w} / \mathrm{v})$ and $0 \%(\mathrm{w} / \mathrm{v})$ of glucose. These results indicated that the presence of high concentrations of carbohydrate in the medium interferes with the growth and friability of calli. 
The stage of calli induction and biomass production is very difficult. Gopi and Vatsala (2006) achieved better results for callus induction in leaves and stems of Gymnema sylvestre on MS medium with $0.5 \mathrm{mg} . \mathrm{L}^{-1}$ of 2,4-D (2.26 mM). Antognoni et al. (2007) induced callus from leaves of Passiflora spp in MS basal medium supplemented with kinetin and 2,4-D. In this case, the synthetic auxin is essential to initiate calluses without metabolite production. There are few reports of calli cultivated in vitro, especially in the genus Boerhavia. Santos et al. (2007) induced callus from leaves and stems of $B$. coccinea in MS medium supplemented with various growth regulators, including 2,4-D. Sudarshana et al. (2008) obtained better results in callus formation from leaf explants of $B$. diffusa in MS supplemented with 2,4-D. Rownaq and Hossain (2010) induced callus of $B$. repens from nodal segments in MS medium containing $1.0 \mathrm{mg} \mathrm{l}^{-1} \mathrm{NAA}$ and $1.0 \mathrm{mg} \mathrm{l}^{-1}$ BAP. The use of synthetic 2,4-D induces calluses without metabolites production, although $\mathrm{BAB}$ or NAA slightly induces metabolite production. The importance of this phenomenon is that the metabolite accumulation delays the growth development.

The species $B$. paniculata appears to be sensitive to culture media with higher osmotic potential, and when cultured in $1 / 2$ MS treatments and coconut water $(10 \% \mathrm{v} / \mathrm{v})$ without glucose, the induction of callus is best evidenced. In the same way, only inorganic salts of MS basal medium have a high osmotic potential $(-0.212 \mathrm{MPa})$, and associated with the sugar should further increase this potential in the culture medium (George et al. 2008, Campbell-Falck 2000). This may explain why treatments with the addition of glucose presented a reduction in the induction of calli in culture of cells from this species.

Production of CAllus Biomass

The $1 / 2$ MS medium with glucose $1.5 \%(\mathrm{w} / \mathrm{v}), 2.26$ $\mu \mathrm{M}$ of 2,4-D and coconut water $10 \%(\mathrm{w} / \mathrm{v})$ favored the increase of callus biomass of $B$. paniculata, and has kept the friability and intense growth with beige and brown color (Figure 1). Furthermore, the subcultured callus under these conditions became dark brown and the growth slowed considerably, showing that the cells started to produce secondary metabolites. The metabolites accumulation was induced by the lack of carbon source on prolonged cultivation that comes as a function of the stress caused by the lack of nutrients in the culture medium. The type and concentration of growth regulators in the culture medium are factors in the growth and development patterns of calli in most in vitro systems (Hartmann et al. 2002). The positive action of auxins, especially 2,4-D on calluses induction in explants of different species has been observed by several authors (Antognoni et al. 2007, Gopi and Vatsala 2006, Sudarshana et al. 2008, Thomas and Maseena 2006), and 2,4-D, as known, is the synthetic auxin which has the function of speeding up the division of cells, leading to rapid growth of the B. paniculata's callus (Santos et al. 2007).

\section{PRODUCTION OF BIOMASS}

The growth of callus biomass of B. paniculata versus time was investigated to check the influence of nutrient consumption. Approximately $1.5 \mathrm{~g}$ of friable callus growing actively were used as inoculum in a maintenance medium $(1 / 2 \mathrm{MS}$ medium with glucose $1.5 \%(\mathrm{w} / \mathrm{v}), 2.26 \mu \mathrm{M}$ of $2,4-\mathrm{D}$ and coconut water $10 \%$ $(\mathrm{v} / \mathrm{v})$. At the beginning of the culture, the callus grew slowly; from the 5th day there was a rapid growth of biomass up to 25 days. After this period, it could be observed a reduction of the biomass growth. The maximum increase in fresh biomass was observed at 25 days of cultivation (Figure 2). The calluses remained friable and beige colored during 30 days, then began the process of browning, probably a result of depletion of the source of carbohydrates and nutrients in the culture medium. The callus showed high amount of water that can be seen by the ratio FW/DW, confirming the friability. Similar results were obtained by Gopi and Vatsala (2006) in callus culture of Gymnema sylvestre. 


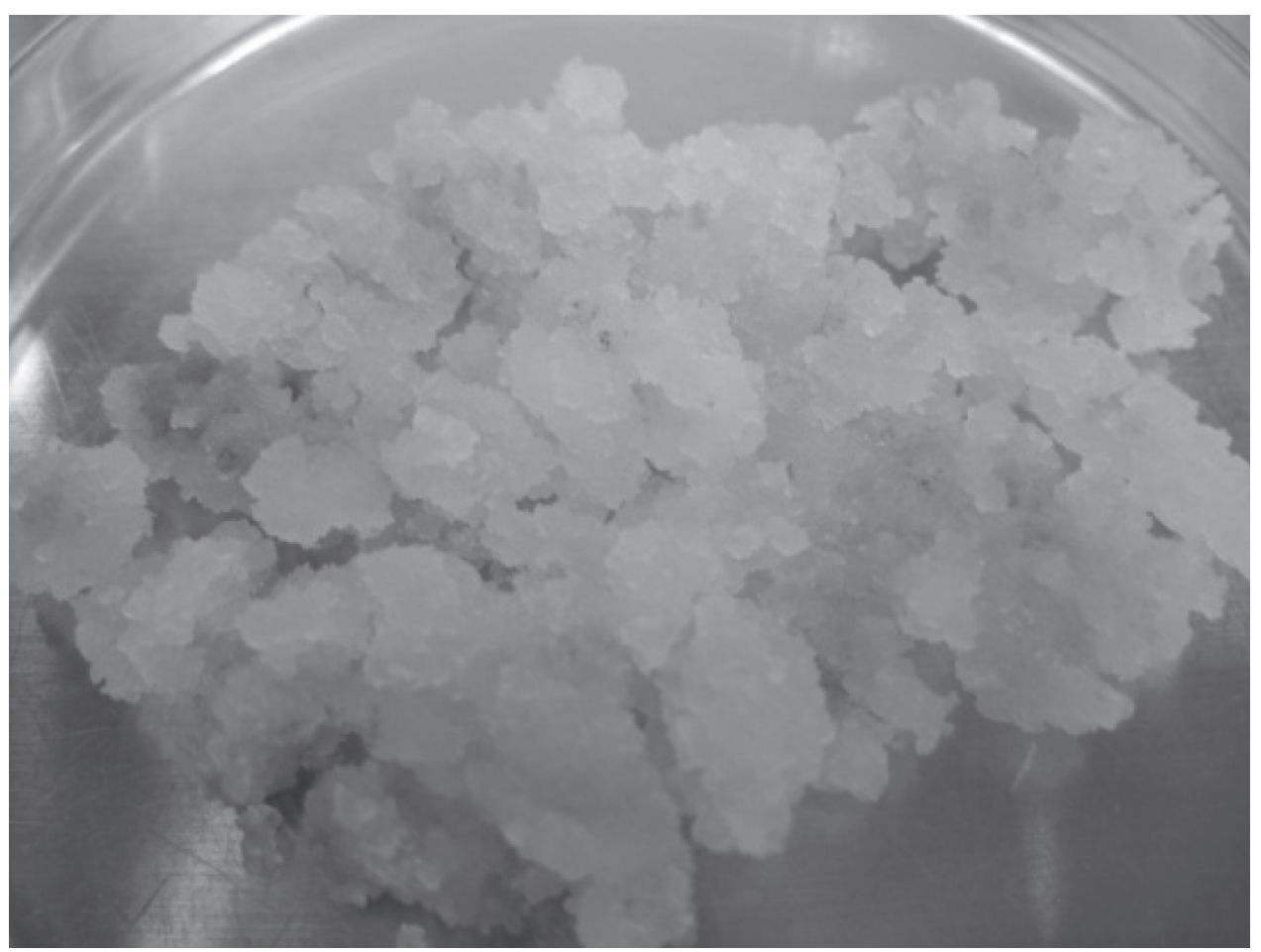

Figure 1 - Callus of Boerhavia paniculata Rich. from seed without coats in $1 / 2 \mathrm{MS}$ medium supplemented with $10 \%(\mathrm{v} / \mathrm{v})$ coconut water and $1.5 \%$ of glucose and $2.265 \mu \mathrm{M}$ of $2,4-\mathrm{D}(\mathrm{w} / \mathrm{v})$ sub-cultivated after 60 days.

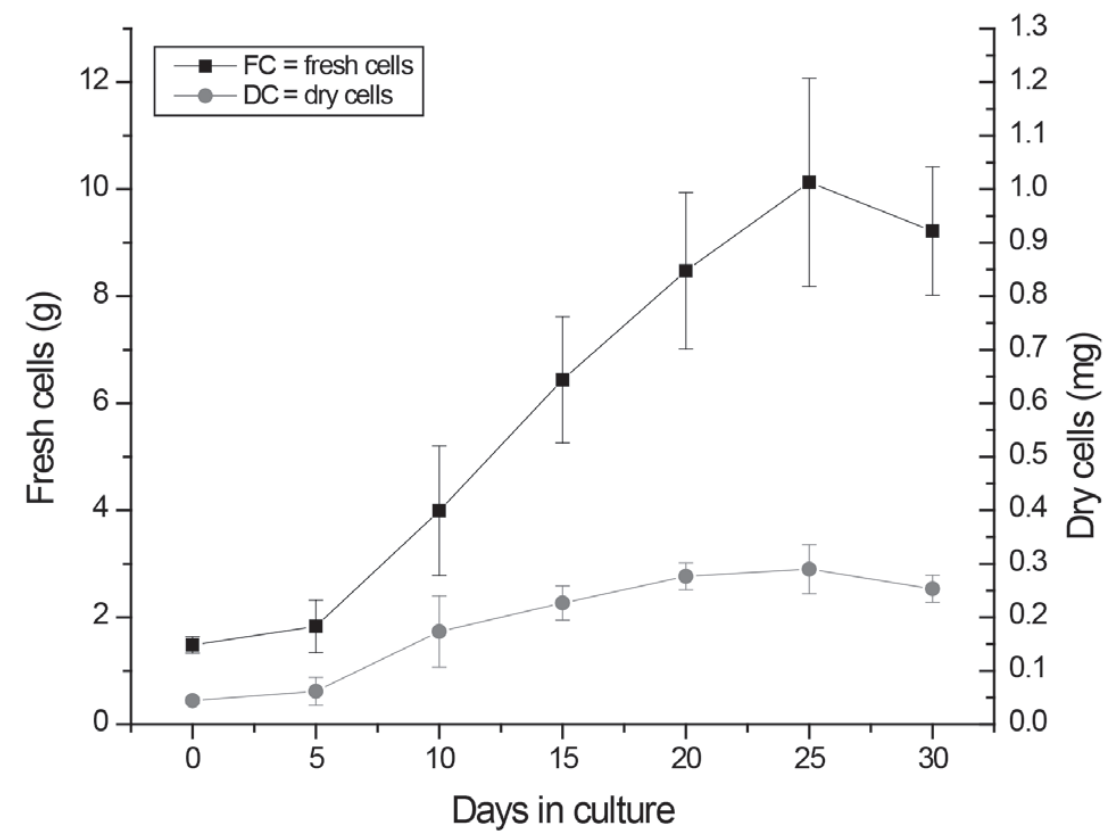

Figure 2 - Curve of calli growth of Boerhavia paniculata Rich in $1 / 2$ MS medium supplemented with $1.5 \%$ glucose $(\mathrm{w} / \mathrm{v}), 2.265 \mu \mathrm{M}$ of $2,4-\mathrm{D}(\mathrm{w} / \mathrm{v})$ and $10 \%$ coconut water $(\mathrm{v} / \mathrm{v})$. Fresh weight $(\mathrm{FW})$ and dry weight $(\mathrm{DW})$ measured during 35 days by sacrifice sampling. 
LiPID Profile of Callus of B. Paniculata

The callus' hexane fraction was analyzed and the lipid profile showed fatty acids and steroids as major substances. Thus PUFAs are presented and seem to be the important group with anti-inflammatory activity, although the major compounds related are: octadecanoic acid (26.3\%), octadecenoic acid (6.9\%), octadecadienoic acid (6.3\%), eicosanoic acid (5.4\%), hexadecanoic acid (2.5\%) and docosanoic acid (1.2\%), hexadecanoic acid methyl ester (47.4\%), $\beta$-sitosterol (0.2\%) and stigmasterol $(0.04 \% ; 0.67$ $\mu \mathrm{g})$. In general, all the compounds present in the profile are found in little amount and are related with plant metaboloma. It is noteworthy that the hexane fraction from roots of $B$. paniculata presented antiinflammatory activity, been found the PUFAs as the principal responsible for the anti-inflammatory effect. However, these compounds were not investigated separately. In general, the presence of unsaturated fatty acids and steroids can have great influence on this activity. One of the characteristic features of lipids is the protective effect against arthrosclerosis, cardiac arrhythmias, inflammatory conditions and immune dysfunction. Other studies show that n-3 PUFA has presented clinical benefit in diseases such as rheumatoid arthritis (Porter, 2010) and long-chain n-3 PUFA are present in the profile of hexane fraction. Table II shows the lipid profile of the hexane fraction found in callus cultures of $B$. paniculata. The total yield of lipid in hexane fraction was $1.8 \mathrm{mg}$ of lipid per $100 \mathrm{mg}$ of callus dry weight.

The total lipid contents either in the callus and wild roots plant did not differ, emphasizing that the compounds present could be produced in the callus culture. The lipid fraction of wild plant reduced $77.3 \%$ of inflammatory cells compared with control and presented similar profile, this result is described by Souza (2012) and has been deeply investigated by our research group. In this sense, it is important to highlight the application of metabolomics to identify the substances present in the lipidic fraction of this callus. Although the most important results presented on this paper are the goals for the protocol to induce and produce high amount of friable callus using seeds from species of Nyctaginaceae as explant, only now the report of the chemical profile of the hexane extract of callus culture from Boerhaavia's genus and the anti-inflammatory activity are being related for the first time.

\section{CONCLUSION}

The present study showed the effectiveness of the protocol to induce and improve calli of Boerhaavia. The current finds highlighted the differential effects of 2,4-D, coconut water and carbohydrate interaction on the proliferation of calli. These results indicated that $1 / 2 \mathrm{MS}$ medium supplemented with coconut water $(10 \%), 2.265 \mu \mathrm{M}$ of $2,4-\mathrm{D}$ and glucose $(1,5 \% \mathrm{w} / \mathrm{v})$ was the best composition to induce calli from seeds without tegument, been obtained high amount of friable callus. The lipid profile obtained from callus of $B$. paniculata confirms the presence of fatty acids; esters and phytosterols indicating that calli have similar chemical substances as the profile of the hexane extract of wild species. This work contributes to the development of an efficient protocol for callus induction, increasing knowledge about the in vitro cultivation of the species B. paniculata.

Further studies must be performed on the qualitative and quantitative changes of lipids, stability of production during a cycle of culture and research on biological activities in callus cultures of this species.

\section{ACKNOWLEDGMENTS}

The authors wish to thank Conselho Nacional de Desenvolvimento Científico e Tecnológico (CNPq), Coordenação de Aperfeiçoamento de Pessoal de Nível Superior (CAPES) and Fundação Amazônia Paraense de Amparo à Pesquisa (FAPESPA) for the financial support. 
TABLE II

Lipid profile of calli hexanic fraction from Boerhaavia paniculata Rich analyzed by GC-MS.

\begin{tabular}{|c|c|c|c|}
\hline CLASSIFICATION & RI & $\begin{array}{c}\text { Roots } \\
\mu \mathrm{g}\end{array}$ & $\begin{array}{c}\text { Callus } \\
\mu g^{*}\end{array}$ \\
\hline \multicolumn{4}{|c|}{ FATTY ALCOHOL AND OTHER COMPOUNDS } \\
\hline Glycerol & 1279 & $\operatorname{tr}$ & 0.63 \\
\hline Octadecanol & 2159 & $\operatorname{tr}$ & 0.04 \\
\hline 1-Hexadecanoilglycerol & 2601 & 0.20 & 0.26 \\
\hline \multicolumn{4}{|c|}{ HYDROXYLATED FATTY ACIDS OR ESTER } \\
\hline 2-hydroxy-tetracosanoic acid & 2920 & $\operatorname{tr}$ & 0.34 \\
\hline Methyl hexadecanoate & 1927 & 805.40 & 757.91 \\
\hline \multicolumn{4}{|l|}{ SATURATED FATTY ACIDS (FA) } \\
\hline Tetradecanoic acid & 1724 & 0.90 & 1.11 \\
\hline Pentadecanoic acid & 1826 & 0.33 & 0.47 \\
\hline Hexadecanoic acid & 1925 & 2.10 & 2.28 \\
\hline Heptadecanoic acid & 2028 & 7.30 & 5.58 \\
\hline Octadecanoic acid & 2128 & 516.30 & 420.83 \\
\hline Eicosanoic acid & 2331 & 95.40 & 86.25 \\
\hline Heneicosanoic acid & 2631 & $\operatorname{tr}$ & 0.14 \\
\hline Docosanoic acid & 2532 & 11.20 & 19.09 \\
\hline Tricosanoic acid & 2629 & 2.10 & 1.16 \\
\hline Tetracosanoic acid & 2733 & 12.70 & 10.74 \\
\hline Pentacosanoic acid & 2833 & $\operatorname{tr}$ & 0.46 \\
\hline Hexacosanoic acid & 2928 & $\operatorname{tr}$ & 0.70 \\
\hline \multicolumn{4}{|c|}{ MONOUNSATURATED FATTY ACIDS (MUFA) } \\
\hline 7-Hexadecenoic acid & 1905 & 42.50 & 39.66 \\
\hline Cis10-Heptadecenoi acid & 2028 & 3.10 & 2.08 \\
\hline Octadecenoic acid & 2105 & 15.0 & 109.69 \\
\hline Octadecenoic acid (isomer) & 2110 & - & 18.12 \\
\hline Eicosenoic acid & 2308 & 0.40 & 6.81 \\
\hline \multicolumn{4}{|c|}{ POLYUNSATURATED FATTY ACIDS (PUFA) } \\
\hline Octadecadienoicacid & 2098 & 86.30 & 100.61 \\
\hline Octadecadienoic acid (Isomer) & 2108 & - & 10.07 \\
\hline \multicolumn{4}{|l|}{ STEROLS (ST) } \\
\hline Stigmasterol & 3307 & 1.9 & 0.67 \\
\hline Sitosterol (Unknown) & 3380 & - & 0.16 \\
\hline Sterol (Unknown) & 3274 & - & 0.62 \\
\hline$\beta$-Sitosterol & 3371 & 3.3 & 3.53 \\
\hline $\begin{array}{l}* \mu g \text { of compounds per } 100 \mathrm{mg} \text { of dry cells. } \\
\text { RI-Retention index, } \operatorname{tr}<0.05 \text {. }\end{array}$ & Total amounts & 1606.43 & 1600.01 \\
\hline
\end{tabular}




\section{RESUMO}

Neste estudo, um protocolo para induzir maiores quantidades de calos friáveis de Boerhaavia paniculata $\mathrm{RICH}$ e uma técnica de lipidômica foram aplicados para investigar o perfil dos lipídios e serem comparados com aqueles presentes nas raízes desta planta, os quais apresentaram atividade anti-inflamatória no extrato hexânico bruto. A cultura de calo foi induzida a partir de sementes em meio sólido contendo sais de Murashige e Skoog com diferentes quantidades de glicose e diferentes concentrações de ácido 2,4-diclorofenoxiacético. Os frascos foram mantidos em câmara de germinação a $30 \pm 2^{\circ} \mathrm{C}$, com fotoperíodo de $16 \mathrm{~h}$ sob intensidade luminosa de $27 \mu \mathrm{mol} \mathrm{m} \mathrm{m}^{-2} \mathrm{~s}^{-1}$ durante 4 semanas. Os melhores resultados para a formação de calo friável e desenvolvimento da biomassa foram obtidos no tratamento contendo 2,26 $\mu \mathrm{M}$ de 2,4-D e de glicose (1,5\% ; $\mathrm{m} / \mathrm{v}$ ). Técnica de lipidômica foi aplicada na fração hexânica mostrando as concentrações mais elevadas de esteróides $\beta$-sitosterol (3,53 mg/100 g de cs - células seca ), e ácidos graxos; especialmente o ácido 2-hidroxi-tetracosanóico (0,34 mg/100 g cs), ácido eicosanoico (86,25 mg/100 g cs), ácido esteárico (420,83 mg/100 g cs), ácido tetradecanóico (10,74 mg/100 g cs) e ácido linoléico (100,61 mg/100 g cs). O perfil lipídico do calo versus aquele encontrado nas raízes da planta silvestre é descrito neste trabalho.

Palavras-chave: lipídios anti-inflamatórios, Boerhaavia paniculata, cultura de calos, perfil lipídico, planta medicinal.

\section{REFERENCES}

ABRAham S, Augustine J AND Thomas TD. 2012. Asymbiotic seed germination and in vitro conservation of Coelogyne nervosa A. Rich. an endemic orchid to Western Ghats. Physiol Mol Biol Plants 18(3): 245-251.

Antognoni F, Zheng S, Pagnucco C, Baraldi R, Poli $\mathrm{F}$ AND BIONDI S. 2007. Induction of flavonoid production by UV-B radiation in Passiflora quadrangularis callus cultures. Fitoter 78: 345-352.

BALANDRIN MF AND KLOCKE JA. 1988. Medicinal, aromatic and industrial materials from plants. In: Bajaj YPS (Ed), Biotechnology in Agriculture and Forestry medicinal and aromatic plant, Springer-Verlag, Berlin, Heidelberg, p. 1-36.

BRASILEIRO ACM AND LACORTE C. 1998. Interação Agrobacterium-Hospedeiro. In: Brasileiro ACM and Carneiro VTC (Eds), Manual de Transformação genética de Plantas, Brasília, DF: Embrapa-SPI-Embrapa-Cenargen, p. 75-92.
CAMPBell-Falck D, Thomas T, FAlck TM, Tutuo N AND CLEM K. 2000. The Intravenous use of coconut water. Amer J Emerg Med 18(1): 108-111.

DiCOSMO F AND MisAWA M. 1995. Plant cell and tissue culture: alternatives for metabolite production. Biotech Advan 13(3): 425-453.

Fuentes SRL, CALHeiros MBP, MANETTI-Filho J AND VIEIRA LGE. 2000. The effects of silver nitrate and different carbohydrate sources on somatic embryogenesis in Coffea canephora. Plant Cell Tiss Org Cult 60: 5-13.

GE L, Yong JWH, GOH NK, CHIA LS, TAN SN AND ONG ES. 2005. Identification of kinetin and kinetin riboside in coconut (Cocos nucifera L.) water using a combined approach of liquid chromatography- tandem mass spectrometry, high performance liquid chromatography and capillary electrophoresis. J Chrom B 829: 26-36.

GE L, Yong JWH, TAN SN, YANG XH AND ONG ES. 2004 Analysis of some cytokinins in coconut (Cocos nucifera L.) water by micellar eletrokinetic capillary chromatography after solid-phase extraction. J Chrom A 1048: 119-126.

George EF, Hall MA AND DE Klerk GJ. 2008. Plant propagation by tissue culture. $3^{\text {rd }}$ ed., Exegetics, UK, 508 p.

GOPI C AND VATSALA TM. 2006. In vitro studies on effects of plant growth regulators on callus and suspension culture biomass yield from Gymnema sylvestre. R. Br. Afric J Biotech 5(12): 1215-1219.

GRATTAPAGLIA D AND MACHAdO MA. 1998. Micropropagação. In: Torres AC, Caldas LS and Buso JA (Eds), Cultura de tecidos e transformação genética de plantas. Brasília, EMBRAPA, p. 183-260.

Gupta RK, SRivastava A AND Verma HN. 2004. Callus Culture and Organogenesis in Boerhaavia diffusa: A Potent Antiviral Protein containing Plant. Physiol Mol Biol Plants 10(2): 263-268.

Hartmann HT, Kester DE and Davies JR. 2002. Plant propagation: principles and practices. Prentice-Hall/ Englewood Cliffs, New Jersey, $7^{\text {th }}$ ed., Upper Saddle River, Prentice Hall, 880 p.

IQBAL H, SHER Z AND KHAN ZU. 2011. Medicinal plants from salt range PindDadan Khan, district Jhelum, Punjab, Pakistan. J Med Plant Res 5(11): 2157-2168.

JiAO J, CARELlA AJ, STEENO GS AND DARRINGTON RT. 2002. Optimization of triple quadrupole of trace degradants of pharmaceutical compounds. Intern J Mass Spec 216(2): 209-218

Kanwar K, Joseph J AND DeEPIKA R. 2010. Comparison of in vitro regeneration pathways in Punica granatum L. Plant Cell Tiss Org Cult 100: 199-207.

Karthikeyan A, Shilpha J, KarUtha PANDIAN S AND RAMESH M. 2012. Agrobacterium-mediated transformation of indica rice cv. ADT 43. Plant Cell Tiss Org Cult 109: 153-165.

LINDSEY K AND JONES MGK. 1992. Biotecnologia vegetal agrícola. Cap. 2. Editorial Acribia, Zaragoza - Espanha, 276 p.

MÉNDEZ IEC, MARTíneZ RR AND GonZÁLEZ AD. 2001. Boerhaavia spp. Rev Cub Plant Med 2: 67-72. 
MHASKAR AV, PRAKASH K, VISHWAKARMA KS AND MAHESHWARL VL. 2010. Callus induction and antimicrobial activity of seed and callus extracts of Clitoria ternatea L. Curr Trends Biotech and Pharmacy 3(4): 561-567.

Mulabagal V AND TsaY HS. 2004. Plant Cell Cultures: an alternative and efficient source for the production of biologically important secondary metabolites. Inter Jour App Sci and Eng 2(1): 29-48.

Murashige T AND Skoog F. 1962. A revised medium for rapid growth and bioassays with tobacco tissue cultures. Physiol Plantarum 15: 473-497.

PaIVA Neto VB AND OTONI WC. 2003. Carbon sources and their osmotic potential in plant tissue culture: does it matter. Sci Hortic 97: 193-202.

Peixe A, Raposo A, Lourenço R, CARdoso H And Macedo E. 2007. Coconut water and BAP successfully replaced zeatin in olive (Olea europaea L.) micropropagation. Sci Hortic 113: 1-7.

Petersen KK, Hansen J AND KrogStrup P. 1999. Significance of different carbon sources and sterilization methods on callus induction and plant regeneration of Miscanthus x ogiformis Honda "giganteus". Plant Cell Tiss Org Cult 58: 189-197.

PORTER J. 2010, The role of Long Chain Fatty acid (n-3 PUFA) supplementation in Rheumatoid arthritis The Plymouth Student Journal of Health \& Social Work 2: 12-18.

RAMACHANDRAN RAO S AND RAVISHANKAR G. 2002. A Plant Cell Cultures: Chemical factories of secondary metabolites. Biotech Adv 20: 101-153.

RoWNAQ A AND HOSSAIN MS. 2010. In vitro direct and indirect plantlets regeneration from nodal segment of Boerhaavia repens L. Int Jour Sustain Crop Prod 5(4): 5-10.

RoY PK. 2008. Rapid multiplication of Boerhaavia diffusa L. through in vitro culture of shoot tip and nodal explants. Plant Tiss Cult Biotech 18(1): 49-56.

SÁ CFC. 2011. Nyctaginaceae in Lista de Espécies da Flora do Brasil. Jardim Botânico do Rio de Janeiro. http://floradobrasil. jbrj.gov.br/2010/FB025888. Accessed 28 May 2012.

SAMBROOK J, FRITSCH EF AND MANIATIS T. 1989. Molecular cloning: a laboratory manual. New York: Cold Spring Harbor Laboratory Press, 252 p.
Santos AS, AraúJo SF, Goulart HF, CAEtano LC, ARrudA MSP, SANTOS LS AND SANTA'ANA AEG. 2007. A dehydrorotenoid produced by callus tissue culture and wild plant roots of Boerhaavia coccinea. Braz Jour Pharm 17(4): 538-541.

SoUZA JMM. 2012. Avaliação da atividade biológica e do perfil metabólico de extratos de calos, células em suspensão e raízes de Boerhaavia paniculata por meio da técnica de lipidômica. Tese de Doutorado. Universidade Federal do Pará. Instituto de Ciências Exatas e Naturais. PPGQ,126 p.

Souza JMM, TOMAZ ML, ARruda SCC, DemÉtrio CGB, VENABLES WN AND MARTINELLI AP. 2011. Callus sieving is effective in improving synchronization and frequency of somatic embryogenesis in Citrus sinensis. Biol Plantarum 55(4): 703-307.

SUDARSHANA MS, NIRANJAN MH AND GIRISHA ST. 2008. In vitro flowering, somatic embryogenesis and regeneration in Boerhaavia diffusa Linn. - A medicinal plant. Glob Jour Biotech Biochem 3(2): 83-86.

Thomas TD AND MaseEnA EA. 2006. Callus induction and plant regeneration in Cardiospermum halicacabum Linn. an important medicinal plant. Sci Hort 108: 332-336.

Tropicos. 2011. Missouri Botanical Garden. http://www. tropicos.org/Name/22500021/. Accessed 04 July 2011.

WeldeGERIMA B. 2009. Review on the importance of documenting ethnopharrmacological information on medicinal plants. Afric Jour of Pharm and Pharmacol 3(9): 400-403.

YONG JWH, GE YL, NG YF AND TAN SN. 2009. The chemical composition and biological properties of coconut (Cocos nucifera L.) water. Molecules 14: 5144-5164.

VAN Ruth S, Boscaini E, MaYr D, PUGH J AND Posthumus M. 2003. Evaluation of three gas chromatography and two direct mass spectrometry techniques for aroma of dried red bell peppers. Inter Jour Mass Spect 223-224: 55-65.

WANG M AND HA Y. 2007. An electrochemical approach to monitor $\mathrm{pH}$ change in agar media during plant tissue culture. Biosen and Bioelectron 22: 2718-2723.

ZACCAI M, JiA G, CHEN X, GENIS O, FEIBIN D AND GESUA R. 2007. Regeneration and transformation system in Mirabilis jalapa. Sci Hortic 111: 304-309. 